\section{Are brand extensions of healthy products an adequate strategy when there is a high association between the brand and unhealthy products?}

\author{
Lorena Carrete ${ }^{1}$ \\ Pilar Arroyo ${ }^{1}$ \\ Edgar Centeno ${ }^{1}$ \\ ${ }^{1}$ Tecnologico de Monterrey, EGADE Business School, Mexico City, Mexico
}

Received on

05/23/2017

Approved on

$01 / 31 / 2018$

\section{Responsible editor:}

Prof. Dr. Susana Costa e Silva

\section{Evaluation process:}

Double Blind Review

\begin{abstract}
Purpose - The objective of this paper was to explore which branding strategy (brand extension versus new brand) is most convenient for healthy products, by taking into account the effect that the perceived fit between the nutritional attributes of the regular products of the parent brand and the healthy extensions have on the credibility of the latter.

Design/methodology/approach - The required information was obtained through personal interviews with 107 consumers resident in the metropolitan area of Mexico City. The type of study was exploratory-descriptive and focused on the manufactured snacks that are sold in Mexico.

Findings - Reformulations of traditional snacks that are commercialized under the name of the parent brand have low credibility with respect to their nutritional value due to the high association between non-healthy attributes and the image of the parent brand. The snacks categorized as healthy are products with well differentiated ingredients but with low brand familiarity.
\end{abstract}

Originality/value - The branding of healthy brands is an incipient area of research in marketing, and thus this paper contributes to the theoretical development of strategies for the commercialization of these brands.

Keywords - brand extension, health brands, branding, food, Mexico.

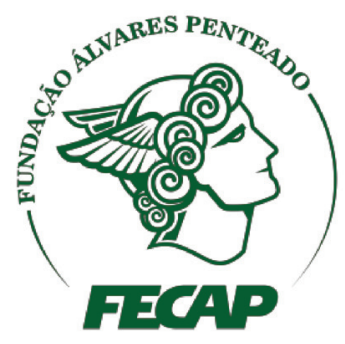

Review of Business Management

DOI: $10.7819 /$ rbgn.v0i0.3905 


\section{Introduction}

The theme of healthy eating has been on the international agenda and on the governmental agenda of many countries for several decades. For example, since 1992 the United Kingdom has promoted an alimentary regime focused on reducing the consumption of fat, sugar, and sodium, and increasing the consumption of fiber (Secretary of State for Health, 2010). The responsibility for an intake that guarantees a good quality of life extends to consumers and enterprises. In the case of consumers, the Nielsen and NMI international report (Frey \& French, 2014) indicates that the size of the segment interested in good nourishment as a means to prevent and amend health problems is increasing. In an online survey, $89 \%$ of USA consumers reported that the responsibility for being healthy is an individual commitment, although only $70 \%$ stated that they are trying to adopt healthy behaviors such as following a complete and balanced diet. This trend towards healthier consumption represents an opportunity for food manufacturers, which through the development of new products can satisfy the current needs of health-conscious consumers and, at the same time contribute to controlling the social problem that overweight and obesity represents.

The management of health brands (health branding) is a challenge for firms that manufacture foods because they must not only offer products with nutritional properties but also be profitable (Anker, Sandoe, Kamin, \& Kappel, 2011). Even though the capabilities of food manufacturers are critical for the development of innovations with high nutritional value, the successful commercialization of these products carries the risk of not being in agreement with the reputation and image of the firm, and thus it is important to consider marketing aspects (Gehlhar, Regmi, Stefanou, \& Zoumas, 2009). These aspects include considering how the perceived fit between the characteristics of the products of the parent brand and its healthy extensions (products with more ingredients of nutritional value) influence the consumer's attitude towards the new product, because this is a critical antecedent to its acceptance (Buil, Chernatoy, \& Hem, 2009; Kemp \& Bui, 2011).

Many firms are creating brand extensions based on the reformulation of their products in order to obtain healthier (less unhealthy) versions, as in the case of reducing the amount of sodium, sugar, or fats. Other firms are developing completely new categories of products with a high nutritional value (healthy), which are commercialized under new brand names. Although research regarding brand extension has been continuously carried out since the 1990s (e.g. Aaker \& Keller, 1990; Dacin \& Smith, 1994; Völckner \& Sattler, 2006), it has not been extended to the context of healthy brands, therefore explaining the interest of this study, whose objective was to explore which of the two strategies - modified products commercialized as brand extensions versus the introduction of healthy products under a new brand name - is more appropriate taking into account the effect that the fit between the nutritional characteristics of the usual products of the parent brand and the healthy extension may have on the credibility of the latter type of product.

The type of product selected to carry out this research were snacks, due to the following reasons: 1) they are products that satisfy the needs of consumers because they have the basic metaattributes of convenience, fair price, tradition, safety, appetence, taste, and variety (Lusk, 2011); 2) their consumer market is not exclusive to any social class or age segment; 3) snack brands need to modify their products in response to the crisis they face due to restrictive government policies and regulations (for example, the ban on the sale of "junk" food in elementary schools in Mexico); 4) snacks are products that Mexicans frequently consume as appetizers or between meals, and their consumption has grown by about $70 \%$ in recent years, with $4 \mathrm{~kg}$ being consumed by each person every year (CANACINTRA, 2014; Euromonitor, 2013). 
Based on the aforementioned context, the research questions associated with the proposed objective are: What snack brands are perceived by Mexican consumers as healthy? What are the desirable and undesirable attributes of a snack that make the consumer recognize it as healthy? How does the perceived fit between the regular products of a brand and its healthy extensions influence the credibility of the firm's ability to manufacture healthy products in the eyes of the consumer?

This article is organized as follows: after this introduction, a theoretical framework (section 2) is presented to discuss the basic concepts studied in this research; the third section describes the methodology used to collect the data and specifies how it was analyzed; next, section 4 describes and discusses the results by including tables and graphs to support the findings; finally, there is a conclusions section where the theoretical and practical implications derived from the research are reported.

\section{Theoretical Framework}

A brand involves a complex set of rational and emotional attributes that can be tangible or intangible and from which the consumer generates associations that help to form his/ her knowledge about the brand (Keller, 2003). Brand associations involve what the firm wants the consumer to remember when comparing with competitors (Aaker, 1991) and reflect the desired positioning of the brand in its market (Dawar \& Lei, 2009). In the case of so-called healthy brands, a series of associations between characteristics of the brand products and healthy consumer styles and behaviors are stimulated in the consumer (Evans \& Hastings, 2008).

One of the attributes involved in this is the brand name, which represents a critical decision for enterprises and is a relevant research topic (Chen, Ma, Zheng, \& Wang, 2015). The name of a brand is not only a symbol of the product's quality, but also generates associations in the consumer that are linked with the functional, social, and psychological value of the attributes of the brand (Teas \& Grapentine, 1996). These associations have a significant effect on the purchase intention of the consumer (Grewal, Krishnan, Baker, \& Borin, 1998). Therefore, an appropriate decision regarding the brand name offers enterprises advantages over their competitors (Del Rio, Vazquez, \& Iglesias, 2001).

The research on brand extensions provides evidence regarding situations where this commercialization strategy works in an assertive manner. An extension of a brand uses the same brand name to launch new products inside the same category or in a different category (Aaker $\&$ Keller, 1990). One of the advantages of this strategy is a reduction in the costs of introducing the new product line, because the consumer is already familiar with the brand and this increases the probability of success of the new line when consumers transfer their favorable attitudes towards the original brand to the extension (Aaker, 1990). There are times when a firm may even use a brand extension to improve the associations that the brand has built in its favor or correct those that may represent a risk (Park, Millberg, \& Lawson, 1991).

However, positive evaluations of brand extensions depend on several elements, the main one being the degree of fit or correspondence between the traditional products of the parent brand and the child products of the brand extension. This perceived fit or compatibility refers to the extent to which the consumer perceives there to be good similarity/correspondence between the parent brand and the extension. A high perceived fit improves the evaluation of the extension (Aaker \& Keller, 1990; Bottomley \& Holden, 2001; Völckner \& Sattler, 2006) and reinforces the appreciation of the parent brand (Zimmer \& Bhat, 2004). If the firm launches a product which is consistent with but not a substitute for those of the parent brand, the consumers perceive a good fit, transfer the qualities of the brand to the extension, judge it to be credible, and thus better evaluate the brand extension and introduce it into their consideration set (Reast, 2005). 
Additionally, when the brand extension is perceived as similar, this results in favorable feedback of the positive evaluations towards the parent brand (Aaker, 1990), strengthening the basic relationship of the brand that makes it different and unique, reinforcing the brand image, contributing to the brand equity, and increasing purchases of products of the same brand (Buil et al., 2009). In contrast, an extension with a low degree of fit may result in a loss in the differentiation and credibility of the firm, weakening the favorable associations of the parent brand (Keller \& Aaker, 1998). Moreover, nonsimilar extensions or ones with a very low fit are questioned by the consumer. In conclusion, a brand extension is more credible, receives better evaluations, and reinforces the appreciation of the parent brand when it is perceived to be similar or consistent with the original products.

Several papers have studied consumer reactions to brand extensions based on the fundamental model developed by Aaker and Keller [A\&K] (1990). Bottomley and Holden (2001), for example, performed a broad analysis of the data collected by $A \& \mathrm{~K}$ to better understand how the quality of the parent brand and its interaction with the perceived fit between the parent brand and the extension influence the attitudes towards the extension. The authors conclude that if the capabilities of the firm manufacturing the original products are perceived to be transferable and complementary to the capabilities required to manufacture the product of the brand extension, this helps the evaluation (Bottomley \& Holden, 2001). However, if the brand extensions are easy to produce (e.g. simple adjustments to existent products) and are not seen as authentic innovations, the extensions may be perceived as attempts to justify price increases. He and $\mathrm{Li}$ (2010) evaluate the effect of the perceived fit between the parent brand and the brand extension in extensions of products with different technological levels. The authors agree that the perceived complementary between the original product and the new one has a more important effect on the attitude of the consumer towards the extension than the perceived substitution.
The evaluation of brand extensions also depends on cultural factors and the type of brand. In this respect, Buil et al. (2009) analyzed the degree to which the perceived fit, the type of brand that offers the extension (high versus medium equity), and the cultural profile of the consumer affect the evaluation of the brand extension along with the equity of the parent brand. Regarding the type of brand, the authors argue that well positioned brand extensions (firms with high organizational capabilities, resources, recognition, and a good image) have a higher probability of being successful because the recognition of the parent brand improves the consumer's perception of the extensions, especially among those consumers with little experience of the brand. This study confirms that a good perceived fit results in more favorable attitudes toward brand extensions, but the most interesting conclusion is that if extensions are perceived as non-similar to the parent brand, the negative impact on the extension and the brand equity is higher in the case of well-recognized brands. Moreover, the extensions of non-lead brands in the market (low equity and low number of followers) may surpass the brand extensions of lead brands when there is a good perceived fit and the alienable differences of the follower are considered to be superior to those of the leader (Liang, Cherian, \& Fu, 2010). These results are of particular importance because they imply that brands with high equity must pay considerable attention to the fit of their brand extensions and offer products with superior attributes that are not seen as naïve modifications to the attributes of the original products.

When creating brand extensions, it is also important to evaluate the effect this will have on the credibility of the brand promise made in the extension (Mitchell \& Edelman, 2003). Brand credibility is an element that supports consumers in deciding which brands to include in their consideration set and increases the probability of purchase (Wang \& Yang, 2010). The concept of brand credibility was introduced by Erdem and Swait (2004) and refers to belief in the truth of the information embedded in the product of a brand 
as being a function of the consumers' perceptions regarding the competence and tendency of the brand to constantly deliver what it promises. This definition contains three elements: the reliability, the experience, and the attractiveness of the brand (Keller \& Aaker, 1998). The reliability has to do with the firm's intention to carry out what it has promised, the experience alludes to the firm's ability to do this, and the attractiveness is related with the firm's image (Erdem \& Swait, 2004; Keller \& Aaker, 1998). The greater the existence of these three components, the higher the brand credibility. Alam, Arshad, and Shabbir (2012), for example, indicate that reliable brands improve credibility, which in turn positively influences consumer loyalty.

The level of credibility also depends on the previous and current experiences the consumer has with the brand. This means all marketing activities contribute to enhancing the consumer's direct and indirect experiences of the brand and influence the brand's current and future credibility (Herbig \& Milewicz, 1993). Keller (2003) indicates that the credibility of the brand is part of its value pyramid and defines it as the consumer's judgment in response to the brand's performance in terms of durability, service, efficiency, effectiveness, empathy, style, design, and price.

Regarding the effects of brand credibility, Erdem and Swait (2004) suggest that credibility reduces the perceived risk of purchase and the information costs, thus increasing the expected utility of the product, which is expressed via a greater purchase intention. In turn, Sinapuelas, Wang, and Bohlmann (2015) demonstrate how the strength of the credibility of the parent brand supports innovation by reducing the consumer's uncertainty regarding the perceived complexity of the new product. Their findings indicate that consumers are interested in testing brand extensions when they are perceived as being highly innovative and come from brands with high credibility. The strength of the brand credibility was shown to be the most important variable when deciding on brand extensions that are perceived as very original, in comparison with other marketing variables such as distribution. In the specific case of the food industry, the literature review regarding the perceived fit between the parent brand and brand extensions carried out by Erfgen, Sattler, and Schnittka (2015) confirms the popularity of the strategy of "transfering" favorable perceptions of the parent brand to new categories of food products and beverages; around 93\% of the new products in the food market were brand extensions. This review suggests that in order to reduce the risk of low similarity with the parent brand it is important to get support from celebrities to increase positive consumer evaluations of the brand extension.

\section{Methodology}

With the purpose of fulfilling the objective of this research by using empirical data, the first step in the methodology was to design a semi-structured questionnaire that enabled the generation of qualitative and quantitative information regarding perceptions about brands of snacks. The instrument began with a filter question to select only those participants who are regular consumers of manufactured snacks (they consume at least three portions of any of these snacks per week); the following questions were organized in four sections according to the informational needs:

1) Exploring what brands of snacks are recognized by consumers as healthy, the nutritional and unhealthy attributes desired/undesired in a healthy snack, and their ranking of importance. Also, in this section the brands of snacks at the forefront of the consumer's mind are examined (6 questions, 5 open and 1 closed).

2) Evaluating the interest in acquiring healthy snacks given the characteristics of the current offer in the market (1 closed question).

3) Determining the credibility of healthy extensions of the brands of snacks, taking into consideration the market 
position of the parent brand (1 closed question). The selected brands were Sabritas (manufactured by PepsiCo), which is the leader in the Mexican market, with a $69.7 \%$ market share, Barcel (part of Bimbo company), with a $20.3 \%$ share of the domestic market, and Bokados (owned by Arca Continental), with a limited presence in the market and only local recognition (northern part of the country) (Tejeda, 2013). The use of actual brands instead of fictitious ones meets the requirements of the academia (e.g. Lei, Pruppers, Ouwersloot, \& Lemmink, 2004) (1 closed question).

4) Demographic data on the consumer (3 closed questions).

The next step was the sample selection. This involved adults between 25 and 50 years old, living in the central part of Mexico (Mexico City and nearby urban area of the State of Mexico), which is of the most populated region in the county and where the two leading snack companies (Pepsico and Barcel) are well recognized (CANACINTRA, 2014; Tejeda, 2013). Adults were selected because youngsters do not assign much value to the nutritional attributes of processed food (Liñán, 2017). The sampling plan was non-probabilistic for convenience; the personal interviews were carried out at five locations with high individual wealth and where a large variety of snacks are sold and consumed: 1 shopping mall, 3 supermarkets (one is the main channel for selling snacks), and 1 school (this is a point of high consumption). The participants were systematically chosen ( 1 of every 10 consumers) in each of the sites selected to apply the survey, and the interviews were performed during a weekday randomly selected for each site. The simple size was $121^{1}$ and at the end of the field work a total of 107 usable questionnaires were obtained, which corresponds to a $94 \%$ response rate in terms of the target sample size.

The last step in the methodology was to analyze the information collected. Descriptive statistical tools were mainly used and to carry out the comparison of the credibility of the brand extensions an Analysis of Variance (ANOVA) was applied, after validating the basic assumptions for its use via a residual analysis.

\section{Analysis and Discussion of Results}

The first part of the analysis consisted of specifying the demographic profile of the interviewees in order to establish the generalizability of the results and/or identify to what segment of consumers the results apply. The sample included individuals of both genders; $63 \%$ were women and $37 \%$ men. The majority of the interviewees were young adults (25-35 years old) with a high educational level; $87 \%$ of the participants had a university degree or even had post-graduate studies. $9.3 \%$ of the interviewees had a middle level education and only $3.7 \%$ had only basic level education. Therefore, the consumers to whom the results of this study apply are young, mainly females consumers with a high educational level.

The information from the first part of the questionnaire was used to establish which brands of snacks are recognized as healthy, which attributes are desirable or undesirable for these snacks, and what the degree of importance of these attributes is to the consumer. Table 1 reports the brands of healthy snacks that the consumers spontaneously recognized.

Table 1.

Snack brands recognized as healthy by the consumer

\begin{tabular}{lc}
\hline Known healthy brand & \% of mentions \\
\hline Does not know any & 36.4 \\
\hline Special K and bars (Kellogg's) & 60.4 \\
\hline Stila (Quaker) & 47.5 \\
\hline Sun Chips (Pepsico) & 35.5 \\
\hline Nature's Heart & 22.4 \\
\hline Twistos (Pepsico) & 20.6 \\
\hline Madre Tierra (Barcel) & 10.3 \\
\hline Ocean Spray & 7.5 \\
\hline Nature Valley & 3.7 \\
\hline
\end{tabular}


Table 2 summarizes the information related with the desirable and undesirable nutritional attributes of a healthy snack (Tudoran, Olsen, \& Dopico, 2009), but traditional attributes such as flavor (taste) are also included because they were taken into account in the consumers' food purchase decision (Maehle, Iversen, Hem, \& Otnes, 2015).

Table 2.

Attributes that a healthy snack should (and should not) have

\begin{tabular}{lccc}
\hline Desirable attributes & \% of mentions & Non-desirable attributes & \% of mentions \\
\hline Low fat content & 52.3 & Bad taste & 25.2 \\
Natural ingredients/no preservatives & 34.6 & High fat content & 23.4 \\
Low caloric content & 28.0 & Chemicals (for enhancing color, & 18.7 \\
& & taste, or preserving food items) & \\
Low sodium content & 19.6 & High price & 11.2 \\
Low sugar content & 13.1 & High salt content & 9.3 \\
High nutritional value & 12.1 & High caloric content & 6.5 \\
High in fiber & 9.3 & & 6.5 \\
Vitamins and minerals & 5.6 & & \\
Protein content & 4.7 & & \\
Nuts, fruits, and vegetables & 4.7 & & \\
\hline
\end{tabular}

In agreement with the observations of Liang et al. (2010), two categories of attributes are distinguished in Table 2, with each group being associated with what a healthy snack "should have" and what it "should not have". Most of the interviewees think that a healthy snack "should not have" a high fat content, additives, sodium, and sugar. To a lesser extent, the consumers think a healthy product "should have" a high nutritional value, fiber, vitamins, minerals, and proteins.

The median levels of importance assigned to the critical ingredients of a healthy snack are reported in Table 3; their importance was compared using the non-parametric KruskalWallis test. The flavor/taste of the product was shown to be the most important attribute for the consumer, even more so than the distinctive nutritional attributes of a healthy snack, which are their naturalness and caloric content. The noteworthy influence that the taste of the product has on the purchase decision has been acknowledged in other studies related to the alimentary practices of individuals in the Mexican context (Carrete \& Arroyo, 2014; SebastiánPonce, Sanz-Valero, \& Wanden-Berghe, 2011).

Table 3.

Importance allocated to the attributes of a healthy snack

\begin{tabular}{llc}
\hline Attribute & Median & $\begin{array}{c}\text { Average ranking of } \\
\text { importance }\end{array}$ \\
\hline $\begin{array}{l}\text { Nutritional } \\
\text { content }\end{array}$ & 3.0 & -1.81 \\
$\begin{array}{l}\text { Natural ingredients } \\
\text { Price }\end{array}$ & 3.0 & -1.57 \\
$\begin{array}{l}\text { Presentation } \\
\text { Taste }\end{array}$ & 5.0 & 3.77 \\
$\begin{array}{l}\text { Comparison of } \\
\text { the ranking of }\end{array}$ & 1.0 & 9.51 \\
$\begin{array}{l}\text { importance of the } \\
\text { attributes (Kruskal- } \\
\text { Wallis test) }\end{array}$ & & -9.90 \\
\hline
\end{tabular}

This first section also explored which brands of snacks are more familiar or wellrecognized by the consumer (Table 4); these brands correspond to those with the greatest sales 
in the Mexican market (CANACINTRA, 2014). Based on this information, it was concluded that the brands of snacks (Sabritas and Barcel) most identified by the consumer (more than $85 \%$ acknowledgment) are the brands owned by the multinational manufacturers Pepsico and Bimbo, which according to the consumers' comments during the interviews, qualitative studies related with this one (Liñán, 2017), and United Nations documents, are categorized among the enterprises that manufacture non-healthy foods (Márquez and Fernández de Gamboa Orrego, n.d.). The products of these brands, which have an extended distribution network, including large and small retailers, stand out in terms of traditional and basic attributes (Maehle et al., 2015) such as accessibility, practicality, and taste (which is associated with their high content of carbohydrates and fats), but which on the other hand are products with low nutritional value, due to their lack of proteins, vitamins, and fiber.

Table 4.

\section{Snack brands known by the consumer}

\begin{tabular}{|l|c|}
\hline Best known snacks & \% of consumers \\
\hline Sabritas Chips (Pepsico) & 96.3 \\
\hline Cheetos (Pepsico) & 96.3 \\
\hline Doritos (Pepsico) & 96.3 \\
\hline Chips (Barcel) & 87.9 \\
\hline Sundry snacks from Barcel & 86.9 \\
\hline Takis (Barcel) & 86.0 \\
\hline Golden Nuts (Barcel) & 84.1 \\
\hline Pepitas (Barcel) & 44.9 \\
\hline Karameladas Pop (Barcel) & 44.9 \\
\hline
\end{tabular}

Based on the information in the tables above, three elements stand out:

1) An important percentage (more than a third) of the consumers does not identify any healthy brand of snacks. The brands that offer healthy snacks are consumed at least once a week by less than $3 \%$ of the consumers; this result is in agreement with the low market share reported for these brands (only $1.2 \%$ of the snack market according to Tejeda, 2013).
2) The healthy brands known by the consumers offer products made with very different ingredients from the ones of traditional snacks such as cereals (Kellogg's and Quaker), seeds, and dehydrated fruits (Nature's Heart and Madre Tierra).

3) The modifications of the traditional products introduced to make them healthier and which are commercialized as brand extensions (for example, Sabritas light and baked Cheetos) were not recognized as healthy brands by the consumers. The brands perceived as healthy are those commercialized under new brand names (Sun Chips and Twistos, manufactured by Pepsico, and Madre Tierra, made by Barcel), but they are little known by the consumer (the difference between the brands of traditional snacks versus healthy snacks is about 35\%).

In summary, the best recognized/identified brands of snacks in Mexico are associated with non-healthy products; therefore, we conclude that there is a high product-brand association. The efforts of the food manufacturers to make their products healthier by reducing the content of fat or salt, which are "undesirable" attributes for a healthy snack (Table 2), and commercializing them as brand extensions, are not enough to modify the consumer's perceptions regarding the nutritional value of these modified products.

Thus, the inference is that there is a poor fit between the parent brands of traditional snacks and their brand extensions. In line with the studies cited by Márquez and Fernández de Gamboa Orrego (n.d.), the brands of traditional snacks have the advantage of a greater purchase intention because they are in the consideration set of the consumer when he/she is looking for nibbles. However, these brands have a strong image in the minds of Mexican consumers as manufacturers of products with a non-healthy image. These strong, consistent, and differentiated associations make it very difficult for the consumer to perceive an appropriate fit between the parent brand and its extension towards the category of healthy snacks. 
This last point is supported by the fact that none of the modified versions of the traditional snacks to make them more nutritious was judged as healthy. In agreement with the conclusions of Bottomley and Holden (2001), the modifications of the traditional snacks are perceived as "too simple or easy" substitutes, incompatible with the concept of an authentic healthy snack, which requires using novel ingredients that are essentially different from those of the well recognized products of the brands of snacks.

To reinforce this argument, to what extent the consumers think a brand of traditional snacks is able to use or enhance its capabilities to develop healthy extensions was evaluated. The credibility measures of brands with different market positions - the market leader (Sabritas), the immediate follower (Barcel), and a brand with limited presence/recognition in the market (Bokados) - were compared. The credibility scores assigned by the interviewees to each of these three brands in terms of their resources and capabilities to produce healthy snacks were contrasted by means of an Analysis of Variance (ANOVA). The results of this analysis are reported in Table 5 and determine that the three brands have statistically equal mean levels of credibility. The graphical analysis of the residuals supported the basic assumptions of independence, constant variance, and normality required by this analysis.

Table 5.

ANOVA comparing credibility of traditional brands in relation to their offer of healthy products

\begin{tabular}{lcccc}
\hline Source of variation & Degrees of freedom & Sum of Squares & Mean Squares & F (P-value) \\
\hline Brand & 2 & 0.914 & 0.457 & $0.63(0.536)$ \\
\hline Error & 310 & 226.593 & 0.731 & \\
\hline Total & 312 & 227.507 & & \\
\hline
\end{tabular}

Thus, a 95\% confidence interval was calculated for the mean credibility perceived by the consumers regarding the ability of the three brands to develop brand extensions. The interval ranges from 2.414 to 2.604 , which according to the categories of the scale used $(1=$ very credible, 2 = somewhat, $3=$ little, $4=$ not at all credible) indicates that there is no credibility of healthy brand extensions in the snack category. These results indicate that even though the parent brand (Bokados) is poorly positioned as a manufacturer of non-healthy snacks, its brand extensions with higher nutritional value have little credibility because of their low fit with the parent brand.

Based on the findings presented above, the leader brands of traditional snacks should reconsider the commercialization of modified products, that is, those with a reduced amount of undesirable ingredients (fats, sodium, or sugar), under the same brand name of the traditional products. A better strategy seems to be to develop more innovative products instead of merely reducing the amount of undesirable ingredients, so that the new healthy products are authentic and distinctive snacks and not just substitutes with less caloric content than the regular snacks (Gehlhar et al., 2009). According to the information collected in the second part of the questionnaire, the consumers think the current offer of healthy snacks is limited. The graph in Figure 1 shows that around $50 \%$ of the interviewees are interested in an increased offer of healthy snacks (median $=2$, which is equivalent to "I would like to have more options of healthy snacks") and 25\% reported a high interest of having a wider offer of such snacks (first quartile $=1$, "I really would like to have more options of healthy snacks"). 


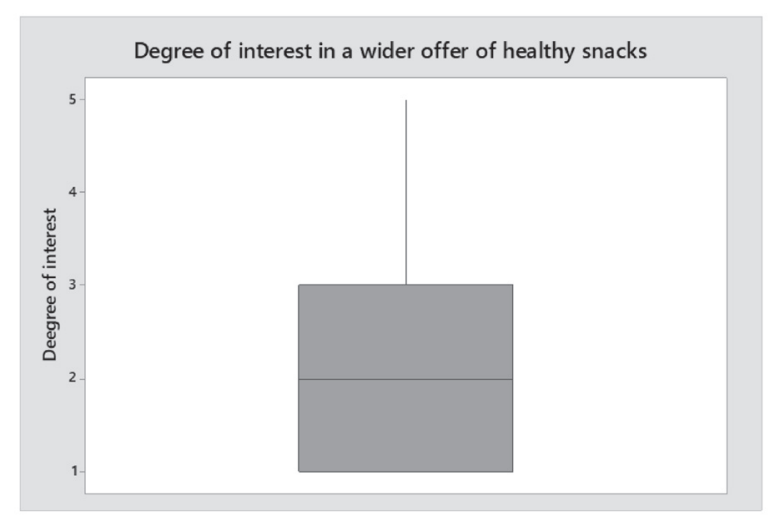

Figure 1. Degree of interest in a good offer of healthy snacks

\section{Conclusions}

The management of healthy brands is an emerging area of research in marketing, for which reason this paper advances the theoretical development of strategies for healthy brands - specifically, the handling of extensions or new brands - by analyzing the impact that the perceived fit has over the credibility of the brand extension. This study provides additional empirical evidence to support the fact that when the image of the parent brand is closely associated with the attributes of a product category, venturing into an "opposite" version will generate inconsistencies for the brand extension, which will have a negative impact on the credibility of the extension (Aaker \& Keller, 1990; Park et al., 1991).

The review by Erfgen et al. (2015) indicates that consumers follow a more fragmented process and use more extrinsic cues to evaluate brand extensions with few similarities. In other words, the evaluation of a healthy brand extension with a low fit with the parent brand stimulates a more elaborate cognitive process. Consequently, the theoretical development of strategies for the management of healthy brands with a low fit can draw from Cue Utilization Theory (CUT) and from the Source of Activation Confusion (SAC) model. According to the SAC model, the evaluation of brand image is inferred from the associations made by the consumer between product attributes or benefits (Stocchi, Wright,
\& Driesener, 2016). From this, remembering a brand is explained as being the result of a memory process that involves both familiarity with the brand and the reminiscence process regarding the qualities of the product, which implies the activation of contextual and casual information. If the brand is familiar to the consumer, it is more likely that he/she will remember it without incorporating details about product attributes. If the brand is not so familiar, however, more information about product attributes must be remembered in order for the consumer to recognize it. Consequently, new brands that venture into the healthy food market will have to activate the nutritional attributes of their products in the consumer's memory so that a positive image of the brand is built. Based on CUT, these attributes should be highlighted in elements such as the design of the packaging, succinct and clear information on nutritional value, and product quality through communications endorsed by health authorities in mass advertising media. Another theoretical perspective of interest is the consideration that brand authenticity is the antecedent of credibility; this authenticity is based on the brand's consistency regarding product attributes and their continued presence (Schallehn, Burmann, \& Riley, 2014). When traditional snack brands venture into the healthy category, they are breaking the consistency and continuity of their offer, which affects the perception of authenticity of the brand and negatively impacts the credibility of its extensions.

Given the strong product-brand association observed in this study, only those brands that are already known as healthy will benefit from the use of high-fit extensions. Therefore, either a healthy brand's name is kept well dissociated from non-healthy brands from the same manufacturer (for example, Quaker versus Sabritas), or an intermediate level of similarity is sought and it is handled as a brand extension. This proposal is in agreement with studies reported in the literature (Erfgen et al., 2015) that suggest that the relationship between similarity or fit with the 
parent brand and the evaluation received by the brand extension is U-shaped, in which moderate similarity (elimination or substitution of notso-healthy ingredients) may have better results than high similarity (complete modification of ingredients).

As for the practical implications of this research, given the gap between the recognition of non-healthy versus healthy snack brands and between the ingredients/attributes of a traditional and a healthy snack, we suggest segmenting the market and highlighting the attributes that are of importance for each segment. Brands recognized as healthy (Table 1) must be directed towards consumers that are highly aware of their health and are concerned with the nutritional quality of the products they buy. These brands could make use of their alignable differences (more nutritional value, antioxidants, fiber, protein, etc.) and underline them in the nutritional and health information of their products (Petrovici et al. 2012) in order to gain the edge over leading snack brands. Additionally, in order for these consumers to better recognize healthy brands, it is important to associate the consumption of a healthy brand with healthy diet practices and enhancements to personal welfare.

Healthy brand extensions, that is, those whose non-desirable ingredients have been reduced, must be directed to the segment of consumers with an intermediate level of health awareness. For this group of consumers, the leading manufacturers could try to offset the nutritional advantages associated with healthy products by enhancing other attributes that are highly valuable to the consumer, such as taste, which turned out to be a critical attribute for those interviewed when choosing snacks. For these consumers, a taste enhancement would lead them to prefer snack brand extensions with an intermediate nutritional value (more desirable nutritional attributes and fewer non-desirable ingredients) (Luomala et al., 2015). This strategy should be complemented with a marketing effort to increase the number of direct and indirect experiences of the product (Espinosa, 2012) in a way that the consumer begins to process the modifications made to the product with the aim of increasing its nutritional value so that the cognitive dissonance between the parent brand and its healthy extension is reduced. Swift launches of healthy extensions generate ruptures in the continuity and consistency of the parent brand and instead of favoring the acceptance of healthy extensions they diminish the authenticity of the brand and impair its credibility (Schallehn et al., 2014). For the segment of consumers for whom the taste of a snack is a critical attribute, it would be very difficult to reconcile attributes that are perceived as incompatible (taste and nutritional value), for which reason they will continue to favor traditional snacks that, even though recognized as "junk" food, have a better taste (Bottomley \& Holden, 2001; Mai \& Hoffmann, 2012).

Another recommendation has to do with brand name strategy. For consumers highly aware of their health, healthy extensions would not be very acceptable because they continue to be associated to the low nutritional value of the product, given the strong brand-snack association, for which reason we would recommend giving brands with a high nutritional value new brand names (Luomala et al., 2015). The strategy of positioning healthy snacks under a new brand name, as in the case of Barcel's Madre Tierra, corrects the low adjustment problem between attributes perceived as incompatible for this segment, and increases the differentiation of the new brand with regard to traditional products and modified extensions of the parent brand. Since these brands are not widely known, the use of expert "spokespersons" or certifications from well-established health organizations is advised so as to endorse the nutritional value of the new brand and recommend it as an appropriate snack between meals. Studies like that of Ríos, Riquelme, and Abdelaziz (2014) conclude that certifications and credibility of the productive capacities of the manufacturer 
increase the preference for products that are not known by the consumer. In the case of healthy brand extensions, a sub-brand strategy might be used to improve the adjustment between parent brand and brand extension (Rahman, 2013). The sub-brand strategy would be the combination of the parent brand's name with another name to develop a product or service with its own brand identity, focused on the market segment with an intermediate level of health awareness.

It is clear that the global tendency towards better quality and variety of high nutritional value (healthy) products represents an opportunity for research on the branding of healthy brands. For instance, an extension to this paper would be an investigation of the way in which the valuable attributes of a product (nutritional value vs. taste) are offset by consumers with different profiles, besides nutritional awareness, in order to strengthen the level of adjustment between parent brand and healthy extension.

Another line of future research would be to explore, from the perspective of corporate social responsibility (CSR), the extent to which manufacturers of foodstuffs are truly interested in developing the healthy snack category, and how these actions contribute to increasing brand credibility and image. The secondary investigation conducted during this study shows a clear preference for continuing to generate income from the traditional snack category and injecting resources to eliminate the less healthy attributes, for this generates immediate financial results. Nonetheless, companies might show greater interest in developing an innovative offer of healthy products if objectives of a social nature were incorporated.

Should the corporate interest in developing new products from established brands continue, it would be interesting to contrast the evaluation of brand extensions for products typified as healthy versus those classified as non-healthy (e.g. yogurt and snacks). This study leaves this question open for future research since it has been demonstrated that the Mexican consumer finds it difficult to adjust his/her perception of the traditional brand and a new healthy category given the high non-healthy brand-product association. It would be necessary to investigate whether it is easier to adjust the positioning and associations of the traditional brand when products are considered healthier per se. Also of interest is the exploration of relationships between the concepts of authenticity, value proposition (healthy, in particular), credibility, and purchase intent for brands perceived as healthy versus those perceived as non-healthy. Lastly, an obvious extension to this study would be to replicate it in other geographical contexts, using probabilistic sampling that increases its external validity and enables the preferences of different geographical markets to be compared.

\section{References}

Aaker, D. (1990). Brand extensions: The good, the bad and the ugly. Sloan Management Review, 31, 47-56.

Aaker, D. (1991). Managing brand equity: Capitalizing on the value of a brand name. New York: Free Press.

Aaker, D., \& Keller, K. (1990). Consumer evaluations of brand extensions. Journal of Marketing, 54(1), 27-41.

Alam, A., Arshad, M. U., \& Shabbir, S. (2012). Brand credibility, customer loyalty and the role of religious orientation. Asia Pacific Journal of Marketing and Logistics, 24(4), 583-598.

Anker, T. B., Sandoe, P., Kamin, T., \& Kappel, K. (2011). Health branding ethics. Journal of Business Ethics, 104, 33-45.

Bottomley, P. A., \& Holden, S. J. S. (2001). Do we really know how consumers evaluate brand extensions? Empirical generalizations based on secondary analysis of eight studies. Journal of Marketing Research, 38(4), 494-502. 
Buil, I., Chernatony, L. D., \& Hem, L. E. (2009). Brand extension strategies: Perceived fit, brand type, and culture influences. European Journal of Marketing, 43(11/12), 1300-1324.

CANACINTRA (2014, Agosto 30). Datos relevantes de la industria de las botanas en México. Retrieved from http://www.botanas.org. $\mathrm{mx} /$ botanas/index.php/industria/datos-de-laindustria

Carrete, L., \& Arroyo, P. (2014). Social marketing to improve healthy dietary decisions: Insights from a qualitative study in Mexico. Qualitative Marketing Research, 17(3), 239-263.

Chen, T., Ma, K., Zheng, C, \& Wang, H. (2015). The effects of sub-brands and brand name structure on extension evaluation: An empirical study based on Chinese culture. Journal of Brand Management, (22)8, 695-713.

Dacin, P., \& Smith, D. (1994), The effect of brand portfolio characteristics on consumer evaluations of brand extension, Journal of Marketing Research, 31(5), 229-242.

Dawar, N., \& Lei, J. (2009). Brand crises: The roles of brand familiarity and crisis relevance in determining the impact on brand evaluations. Journal of Business Research, 62, 509-516.

Del Rio, A. B., Vázquez, R., \& Iglesias, V. (2001). The role of the brand name in obtaining differential advantages. Journal of Product and Brand Management, 10(7), 452-461.

Erfgen, C., Sattler, H., \& Schnittka, O. (2015). How celebrity endorsers enhance parent brand extendibility to low similarity brand extensions. Journal of Business Economics, 85, 479-504.

Erdem, T., \& Swait, J. (2004). Brand credibility, brand consideration, and choice. Journal of Consumer Research, 31(1), 191-198.

Espinosa, E. (2012, Abril 18). Barcel logra reducir 30 por ciento de grasa en sus botanas. Retrieved from http://www.excelsior.com.mx/2012/04/18/ dinero/827516

Euromonitor (2013, Noviembre). Snacks Appeal: How brands identify and exploit food trends. Retrieved from http://www.euromonitor.com/ snacks-appeal-how-brands-identify-and-exploitfood-trends/report

Evans, W. D., \& Hastings, G. (2008). Public health branding: Recognition, promise, and delivery of healthy lifestyles. In W. E. Evans, y G. Hastings (Eds.), Public Health Branding (pp.324). Oxford, UK: Oxford University Press.

Frey, S., \& French, S. (2014). Health \& wellness in America. Part 1. The consumer perspective. New York: The Nielsen Company \& Natural Marketing Institute (NMI).

Gehlhar, M. J., Regmi, A., Stefanou, S. E., \& Zoumas, B. L. (2009). Brand leadership and product innovation as firm strategies in global food markets. Journal of Product \& Brand Management, 18(2), 115-126.

Grewal, D., Krishnan, R., Baker, J., \& Borin, N. (1998). The effects of store name, brand name and price discounts on consumers' evaluations and purchase intentions. Journal of Retailing, 74(3), 331-352.

He, L., \& Li, Y. (2010). Consumer evaluation of technology-based vertical brand extension. European Journal of Marketing, 44(9/10), 13661383.

Herbig, P., \& Milewicz, J. (1993). The relationship of reputation and credibility to brand success. Journal of Consumer Marketing, 10(3), 8-24.

Keller, K. (2003). Strategic brand management: Building, measuring, and managing brand equity. Upper Saddle River, NJ: Pearson Hall.

Keller, K., \& Aaker, D. (1998). Corporatelevel marketing: The impact of credibility on a 
company's brand extensions. Corporate Reputation Review, 1(4), 356-378.

Kemp, E., \& Bui, M. (2011). Healthy brands: Establishing brand credibility, commitment and connection among consumers. Journal of Consumer Marketing, 28(6), 429-437.

Lei, J., Pruppers, R., Ouwersloot, H., \& Lemmink, J. (2004). Service intensiveness and brand extension evaluations. Journal of Service Research, 6(3), 243-255.

Liang, B., Cherian, J., \& Fu, W. (2010). Can followers overcome pioneers? The role of superior alignable differences in consumer evaluation of brand extensions. Journal of Product \& Brand Management, 19(2), 85-93.

Liñán, J. (2017). Healthy Eating: consumers' perceptions of food product healthiness in Mexico. Marketing Research Colloquium, Mexico City, Mexico, 7.

Luomala, H., Jokitalo, M., Karhu, H., HietarantaLuoma, H. L., Hopia, A., \& Hietamäki, S. (2015). Perceived health and taste ambivalence in food consumption. Journal of Consumer Marketing, 32(4), 290-301.

Lusk, J. L. (2011). External validity of food values scale. Food Quality and Preference, 22(5), 452-462.

Maehle, N., Iversen, N., Hem, L., \& Otnes, C. (2015). Exploring consumer preferences for hedonic and utilitarian food attributes. British Food Journal, 117(12), 3039-3063.

Márquez, M., \& Fernández de Gamboa Orrego, A. (s.f.). Composición nutrimental de algunos alimentos chatarra. Retrieved from https:// composicionnutrimentalcomidachatarra. wikispaces.com/

Mai, R., \& Hoffmann, S. (2012). Taste lovers versus nutrition fact seekers: How health consciousness and self-efficacy determine the way consumers choose food products. Journal of Consumer Behaviour, 11, 316-328.

Mitchell, V., \& Edelman, D. J. (2003). How to successfully extend your brand. Marketing Proofs. com. Retrieved from www.marketingproofs. com/3/edelman 1 .asp

Park, C., Millberg, S., \& Lawson, R. (1991, Sept.). Evaluations of brand extensions: The role of product level similarity and brand concept consistency. Journal of Consumer Research, 18, 185-193.

Petrovici, D., Fearne, A., \& Drolias, D. (2012). Nutritional knowledge, nutritional labels, and health claims on food. A study of supermarket shoppers in the South East of England. British Food Journal, 114(6), 768-783.

Rahman, K. (2013). Discovering brand meaning: Deriving the domains of a sub-brand. Market $\&$ Social Research, 21(1), 38-53.

Reast, J. (2005). Brand trust and brand extension acceptance: The relationship. Journal of Product \& Brand Management, 14(1), 4-13.

Ríos, R. E., Riquelme, H. E., \& Abdelaziz, Y. (2014). Do halal certification country of origin and brand name familiarity matter? Asia Pacific Journal of Marketing and Logistics, 26(5), 665-686.

Sebastian-Ponce, M. I., Sanz-Valero, J., \& Wanden-Berghe, C. (2011). Etiquetado y rotulación de los alimentos en la prevención del sobrepeso y la obesidad: Una revisión sistemática. Cadernos de Saúde Pública [online], 27(11), 20832094.

Secretary of State for Health. (2010). Healthy lives, healthy people: Our strategy for public health in England: 2010. Retrieved from https://www. gov.uk/government/publications/healthy-liveshealthy-people-our-strategy-for-public-healthin-england 
Schallehn, M., Burmann, C., \& Riley, N. (2014). Brand authenticity: Model development and empirical testing. Journal of Product \& Brand Management, 23(3), 192-199.

Sinapuelas, I. C., Wang, H.-M., \& Bohlmann, J. (2015). The interplay of innovation, brand, and marketing mix variables in line extensions. Journal of the Academy of Marketing Science, 43, 558-57.

Stocchi, L., Wright, M., \& Driesener, C. (2016). Why familiar brands are sometimes harder to remember. European Journal of Marketing, 50(3/4), 621-638.

Teas, R. K., \& Grapentine, T. H. (1996). Demystifying brand equity. Marketing Research, 8(2), 24-29.

Tejeda, C. (2013, Mayo 23). Libra negocio de botanas campañas antiobesidad. El Economista. Retrieved from http://eleconomista.com.mx/ industrias/2013/05/23/libra-negocio-botanascampanas-antiobesidad

Tudoran, A., Olsen, S. O., \& Dopico, D. C. (2009). The effect of health benefit information on consumers' health value, attitudes and intentions. Appetite, 52, 568-579.

Völckner, F., \& Sattler, H. (2006). Drivers of brand extensions success. Journal of Marketing, $70(2), 18-34$.

Wang, X., \& Yang, Z. (2010). The effect of brand credibility on consumer's brand purchase intention in emerging economies: The moderating role of brand awareness and brand image. Journal of Global Marketing, 23(3), 177-188.

Zimmer, M. R., \& Bhat, S. (2004). The reciprocal effects of extension quality and fit on parent brand attitude. Journal of Product \& Brand Management, 13(1), 37-46. 


\section{APPENDIX}

\section{HEALTHY SNACKS Questionnaire}

Folio No.

\section{Introduction}

This survey involves the consumption of certain products by people aged between 15 and 50 . We would greatly appreciate your help by answering the following questions according to the instructions.

\section{Filter}

F1. Have you consumed at least 3 portions of snacks in the last week? Yes/No

\begin{tabular}{|l|l|l|}
\hline Yes & & $\rightarrow$ Continue \\
\hline No & & $\rightarrow$ End survey \\
\hline
\end{tabular}

F2. Mark your age group

\begin{tabular}{|l|l|l|}
\hline Under 15 & 1 & $\rightarrow$ Finish \\
\hline $\mathbf{1 5}$ to $\mathbf{5 0}$ & 2 & $\rightarrow$ Continue \\
\hline Over 50 & 4 & $\rightarrow$ Finish \\
\hline
\end{tabular}

\section{Main Questionnaire - Knowledge and Use}

\section{BRAND KNOWLEDGE}

$P 1$. Which of the following savory snacks are you familiar with? Mark with an " $X$ " the cell corresponding to the brand(s) that you know.

\begin{tabular}{|l|l|}
\cline { 2 - 2 } \multicolumn{1}{l|}{} & \multicolumn{1}{c|}{ Mark with an "X" } \\
\hline Barcel & \\
\hline Doritos & \\
\hline Takis & \\
\hline Cheetos & \\
\hline Chips & \\
\hline Special K & \\
\hline Ocean Spray & \\
\hline Sun Chips & \\
\hline Twistos & \\
\hline Madre Tierra & \\
\hline Pepitas de Barcel & \\
\hline Golden Nuts & \\
\hline Papas Sabritas & \\
\hline Karameladas Pop & \\
\hline Poffets & \\
\hline Nature's Heart & \\
\hline
\end{tabular}




\section{FREQUENT CONSUMPTION}

P2. Which savory snack brand (potato chips, corn chips, etc.) do you consume most often? Please choose only one brand.

\begin{tabular}{|l|l|}
\cline { 2 - 2 } \multicolumn{1}{c|}{} & \multicolumn{1}{c|}{ Mark with an “X” } \\
\hline Barcel & \\
\hline Doritos & \\
\hline Takis & \\
\hline Cheetos & \\
\hline Chips & \\
\hline Special K & \\
\hline Ocean Spray & \\
\hline Sun Chips & \\
\hline Twistos & \\
\hline Madre Tierra & \\
\hline Pepitas de Barcel & \\
\hline Golden Nuts & \\
\hline Papas Sabritas & \\
\hline Karameladas Pop & \\
\hline Poffets & \\
\hline Nature's Heart & \\
\hline
\end{tabular}

Examining healthy snacks or ones with healthier profiles

P7. What do you think of the offer of healthy snacks?

P8. Which brands of healthy snacks do you know?

\begin{tabular}{|l|}
\hline \\
\hline \\
\hline
\end{tabular}

P9. What characteristics should a snack have in order to be considered healthy?

\begin{tabular}{|l|}
\hline \\
\hline \\
\hline
\end{tabular}

P10. Would you like there to be healthier snack options in the market? Please choose only one answer.

\begin{tabular}{|l|l|}
\hline I would love that. & $\square$ \\
\hline I would really like that. & \\
\hline I would like that. & \\
\hline I would quite like that. & $\square$ \\
\hline I wouldn't really like that. & $\square$ \\
\hline I wouldn't like that at all. & $\square$ \\
\hline
\end{tabular}




\section{Purchase Intention}

P11. If there were healthy snack options, how willing would you be to buy this product if it were on sale?

Mark with an " $X$ " the option that best corresponds and give only one answer.

\begin{tabular}{|l|l|}
\hline I definitely wouldn't buy it. & \\
\hline I probably wouldn't buy it. & \\
\hline I'm not sure. & \\
\hline I'd probably buy it. & \\
\hline I'd definitely buy it. & \\
\hline
\end{tabular}

P12. Besides the corner store, where would it be important for healthy snacks to be sold in order for you to buy them more often? Choose only one option.

\begin{tabular}{|l|l|}
\hline In convenience stores (For example, Oxxo, 7 Eleven, Super K, etc). \\
\hline In supermarkets (Walmart, Commercial Mexicana, Soriana, etc). \\
\hline In price clubs (Costco, SAM's etc.) & \\
\hline In wholesalers (El Puma, El Zorro, etc). & \\
\hline Others (specify): & \\
\hline
\end{tabular}

P13. In which snack category would you prefer healthy snacks? Choose only one option.

\begin{tabular}{|l|l|}
\hline Potato chips & $\square$ \\
\hline Corn (For example: nachos, chips etc.) & $\square$ \\
\hline Nuts and seeds (peanuts, seeds, walnuts, pistachios etc.) & $\square$ \\
\hline Popcorn & $\square$ \\
\hline Puffed snacks & $\square$ \\
\hline Mixtures & $\square$ \\
\hline Other (specify) & $\square$ \\
\hline
\end{tabular}

P14. Of the snacks you know, which characteristic is most important in the packaging? Choose only one option.

\begin{tabular}{|l|r|}
\hline Nutritional information & $1 \square$ \\
\hline Colors & $2 \square$ \\
\hline Easiness to open & $3 \square$ \\
\hline Design & $4 \square$ \\
\hline Other (specify) & $\square$ \\
\hline
\end{tabular}

\section{Spontaneous Dislikes}

P15. What would you NOT like healthy snacks to have?

\section{Spontaneous likes}

P16. What would you most like healthy snacks to have? Please order from highest to lowest, where 1 is what you most like and $\mathbf{5}$ is what you least like.

\begin{tabular}{|l|r|}
\hline Taste & $\square$ \\
\hline Presentation & $\square$ \\
\hline Ingredients & $\square$ \\
\hline Nutritional content & $\square$ \\
\hline Price & $\square$ \\
\hline
\end{tabular}




\section{Uniqueness}

P17. How would you classify the offer of healthy snacks in the market? Choose only one option.

\begin{tabular}{|l|l|}
\hline Extremely new and different & \\
\hline Very new and different & \\
\hline Quite new and different & \\
\hline Hardly new and different & \\
\hline Not new or different at all & \\
\hline
\end{tabular}

\section{Value for Money}

P18. Considering the regular price that you pay for a $\$ 7.00$ pesos snack in the store, do you think healthy snacks...? Choose only one option.

\begin{tabular}{|l|l|}
\hline Could cost a little more & $\square$ \\
\hline Should cost the same & $\square$ \\
\hline Should cost a little less & $\square$ \\
\hline Should cost a lot less & $\square$ \\
\hline Should cost an awful lot less & $\square$ \\
\hline
\end{tabular}

\section{Frequency of future purchase}

P19. How often would you consume the healthy snacks available?

\begin{tabular}{|l|l|}
\hline Once a week or more often & $\square$ \\
\hline Once a month & $\square$ \\
\hline Once every 4 to 6 months & $\square$ \\
\hline Once a year & $\square$ \\
\hline Never & $\square$ \\
\hline
\end{tabular}

\section{Relevance}

P20. If you had to choose between a conventional snack and a snack with the healthy attribute, which would be your first choice? Mark with an "X".

\begin{tabular}{|l|l|}
\hline Conventional & $\square$ \\
\hline Healthy & $\square$ \\
\hline
\end{tabular}

P21. For which brand would a healthy snacks category be credible? Please mark only one option for each brand.

SABRITAS

\begin{tabular}{|l|c|}
\hline Very credible & $\square$ \\
\hline Quite credible & $\square$ \\
\hline Barely credible & $\square$ \\
\hline Not at all credible & $\square$ \\
\hline
\end{tabular}

BARCEL

\begin{tabular}{|l|r|}
\hline Very credible & $\square$ \\
\hline Quite credible & $\square$ \\
\hline Barely credible & $\square$ \\
\hline Not at all credible & $\square$ \\
\hline
\end{tabular}

BOKADOS

\begin{tabular}{|l|r|}
\hline Very credible & $\square$ \\
\hline Quite credible & $\square$ \\
\hline Barely credible & $\square$ \\
\hline Not at all credible & $\square$ \\
\hline
\end{tabular}




\section{Occasions}

P22. When in the day would you usually consume healthy snacks?

\begin{tabular}{|l|l|}
\hline Before breakfast & \\
\hline With/for breakfast & \\
\hline Between breakfast and lunch & \\
\hline With/for lunch & \\
\hline Between lunch and dinner & $\square$ \\
\hline With/for dinner & $\square$ \\
\hline After dinner & $\square$ \\
\hline
\end{tabular}

P23.1 On what occasions would you usually consume healthy snacks? Mark most to least according to your level of preference, where 1 is most preferably and 5 is least preferably.

\begin{tabular}{|l|l|}
\hline In class & \\
\hline In the playground & \\
\hline During break & \\
\hline On the way home & \\
\hline At a match & \\
\hline At a party/get-together & \\
\hline At home watching TV/a movie & \\
\hline At home playing video games & \\
\hline At home surfing the internet & \\
\hline
\end{tabular}

P24. Do you think these products are mainly to consume... Mark only one option.

\begin{tabular}{|l|l|}
\hline Alone & $\square$ \\
\hline With friends & $\square$ \\
\hline With my partner & $\square$ \\
\hline With my family & $\square$ \\
\hline
\end{tabular}




\section{Early adopters identification questions}

Early adopter identification questions

PRODUCT FIELD RISK 1 - EVALUATE

P25. Which of these sentences best describes how you would feel choosing a new product for the first time? If you choose a number to the left, it means that you agree more with the opinion on the left. If you choose one near the right, you agree more with the opinion on the right.

\begin{tabular}{|l|l|l|l|l|l|l|l|r|}
\hline The price is too low to worry me. & 1 & 2 & 3 & 4 & 5 & 6 & 7 & The price is too high to buy it. \\
\hline $\begin{array}{l}\text { I am completely sure it will be safe } \\
\text { to eat. }\end{array}$ & 1 & 2 & 3 & 4 & 5 & 6 & 7 & I am worried it will not be safe \\
to eat.
\end{tabular}

\section{PRODUCT FIELD RISK 2}

P26. Please, indicate which of these sentences best describes how you would feel choosing healthy snacks in general? If you choose a number to the left, it means that you agree more with the opinion on the left. If you choose one near the right, you agree more with the opinion on the right.

\begin{tabular}{|l|c|c|c|c|c|c|c|r|}
\hline $\begin{array}{l}\text { I think carefully about what I'm } \\
\text { going to buy. }\end{array}$ & 1 & 2 & 3 & 4 & 5 & 6 & 7 & $\begin{array}{r}\text { Idon't think there is anything } \\
\text { important to consider before } \\
\text { buying. }\end{array}$ \\
$\begin{array}{l}\text { I always know exactly what brand } \\
\text { I'm going to choose. }\end{array}$ & 1 & 2 & 3 & 4 & 5 & 6 & 7 & $\begin{array}{r}\text { I don't choose the brand until } \\
\text { I've seen all the options. }\end{array}$ \\
\hline $\begin{array}{l}\text { I always buy the same brand as my } \\
\text { last purchase. }\end{array}$ & 1 & 2 & 3 & 4 & 5 & 6 & 7 & $\begin{array}{r}\text { I always buy a different brand in } \\
\text { every purchase. }\end{array}$ \\
\hline
\end{tabular}

\section{PRODUCT FIELD RISK 3}

P27. Thinking in general about the brands of healthy snacks currently available, please indicate which of these sentences best describes your opinion. If you choose a number to the left, it means that you agree more with the opinion on the left. If you choose one near the right, you agree more with the opinion on the right.

\begin{tabular}{|l|l|l|l|l|l|l|l|r|}
\hline $\begin{array}{l}\text { I am completely satisfied with the } \\
\text { brands currently available. }\end{array}$ & 1 & 2 & 3 & 4 & 5 & 6 & 7 & $\begin{array}{r}\text { None of the current brands } \\
\text { satisfies my needs. }\end{array}$ \\
\hline
\end{tabular}

P28. What is your maximum level of schooling?

\begin{tabular}{|l|r|}
\hline Elementary & $\square$ \\
\hline High School & $\square$ \\
\hline Preparatory & $\square$ \\
\hline Professional & $\square$ \\
\hline Postgraduation & $\square$ \\
\hline
\end{tabular}


P29. Please order from the highest to lowest the importance that the following aspects have for you: putting 1 for the most important and $\mathbf{8}$ for the least important aspect.

\begin{tabular}{|l|l|}
\hline Sports & \\
\hline Culture & \\
\hline Fashion & \\
\hline Environment & \\
\hline Personal image & \\
\hline Family & $\square$ \\
\hline Friends & $\square$ \\
\hline
\end{tabular}

THAT IS ALL. THANK YOU VERY MUCH!

\section{Nota}

1 The simple size was computed using the statistical basis even though a convenience sampling plan was used. Assuming a simple random sampling, we defined a $5 \%$ margin of error in the perceived credibility estimate, this rate corresponding to 0.135 units in the four-category credibility scale, ranging from $1=$ very credible to $4=$ not at all credible, used in the survey.

\section{About the Authors:}

1. Lorena Carrete, PhD in management, Tecnologico de Monterrey, EGADE Business School, Toluca, Mexico. E-mail: lcarrete@itesm.mx

ORCID

(iD) 0000-0003-4088-013X

2. Pilar Arroyo, PhD in Bussines and administration, Tecnologico de Monterrey, EGADE Business School, Toluca, Mexico. E-mail: pilar.arroyo@itesm.mx

ORCID

(iD) 0000-0002-6160-871X

3. Edgar Centeno, PhD in Marketing, Tecnologico de Monterrey, EGADE Business School, Mexico City, Mexico. E-mail: ecenteno@itesm.mx

\section{ORCID}

(iD) 0000-0001-9718-8078

\section{Contribution of each author:}

\begin{tabular}{|c|c|c|c|}
\hline Contribution & Lorena Carrete & Pilar Arroyo & Edgar Centeno \\
\hline 1. Definition of research problem & $\sqrt{ }$ & $\sqrt{ }$ & $\sqrt{ }$ \\
\hline $\begin{array}{l}\text { 2. Development of hypotheses or research questions } \\
\text { (empirical studies) }\end{array}$ & $\sqrt{ }$ & $\sqrt{ }$ & $\sqrt{ }$ \\
\hline 3. Development of theoretical propositions (theoretical work) & $\sqrt{ }$ & $\sqrt{ }$ & $\sqrt{ }$ \\
\hline 4. Theoretical foundation/Literature review & $\sqrt{ }$ & $\sqrt{ }$ & $\sqrt{ }$ \\
\hline 5. Definition of methodological procedures & $\sqrt{ }$ & & \\
\hline 6. Data collection & $\sqrt{ }$ & & \\
\hline 7. Statistical analysis & & $\sqrt{ }$ & \\
\hline 8. Analysis and interpretation of data & $\sqrt{ }$ & $\sqrt{ }$ & \\
\hline 9. Critical revision of the manuscript & $\sqrt{ }$ & $\sqrt{ }$ & $\sqrt{ }$ \\
\hline 10. Manuscript Writing & $\sqrt{ }$ & $\sqrt{ }$ & $\sqrt{ }$ \\
\hline
\end{tabular}

